\title{
Nesterenkonia sandarakina sp. nov. and Nesterenkonia lutea sp. nov., novel actinobacteria, and emended description of the genus Nesterenkonia
}

\author{
Wen-Jun Li, ${ }^{1}$ Hua-Hong Chen, ${ }^{1,2}$ Chang-Jin Kim, ${ }^{3}$ Yu-Oin Zhang, ${ }^{1}$

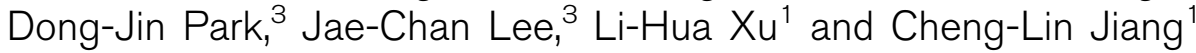 \\ ${ }^{1}$ The Key Laboratory for Microbial Resources of Ministry of Education, PR China, Laboratory \\ for Conservation and Utilization of Bio-Resources, Yunnan Institute of Microbiology, Yunnan \\ University, Kunming, Yunnan 650091, PR China \\ ${ }^{2}$ Department of Chemistry, Chuxiong Normal College, Chuxiong, Yunnan 675000, PR China \\ ${ }^{3}$ Korea Research Institute of Bioscience and Biotechnology, 52 Oeundong, Yusong, Daejeon \\ 305-333, Republic of Korea
}

Correspondence Cheng-Lin Jiang lihxu@ynu.edu.cn or liact@hotmail.com

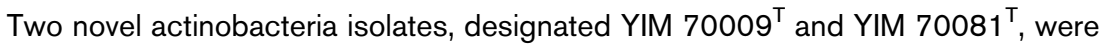
characterized in order to determine their taxonomic position. Cells of strains $\mathrm{YIM} 70009^{\top}$ and YIM $70081^{\top}$ were cocci, although only the latter were motile. The $G+C$ contents of their DNAs were 64.0 and $64.5 \mathrm{~mol} \%$, respectively. On the basis of chemotaxonomic characteristics and 16S rRNA gene sequence analysis, the two isolates were classified in the genus Nesterenkonia. DNA-DNA hybridization and comparison of phenotypic characteristics revealed that strains YIM $70009^{\top}$ and YIM $70081^{\top}$ differed from each other and from known species. Therefore, it is proposed that they represent two separate novel species of the genus Nesterenkonia:

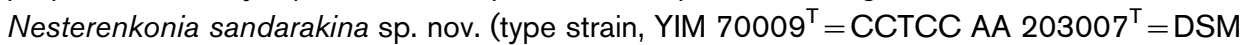
$15664^{\top}=$ KCTC $19011^{\top}$ ) and Nesterenkonia lutea sp. nov. (type strain, YIM $70081^{\top}=\mathrm{CCTCC}$ AA $203010^{\top}=\operatorname{DSM} 15666^{\top}=$ KCTC $19013^{\top}$ ).
The genus Nesterenkonia was first proposed by Stackebrandt et al. (1995) in the reclassification of Micrococcus halobius Onishi and Kamekura 1972 as Nesterenkonia halobia (Stackebrandt et al., 1995). At present, the genus comprises four valid species: N. halobia (Stackebrandt et al., 1995), Nesterenkonia lacusekhoensis (Collins et al., 2002), and Nesterenkonia halotolerans and Nesterenkonia xinjiangensis (Li et al., 2004). In this report, two novel species of the genus Nesterenkonia that were discovered during our taxonomic study of extremophilic actinomycetes are described.

Strain YIM $70009^{\mathrm{T}}$ was isolated from a soil sample collected from the eastern desert of Egypt using modified medium A (supplemented with $15 \% \mathrm{NaCl}, \mathrm{w} / \mathrm{v}, \mathrm{pH} 10 \cdot 0-10 \cdot 5$ ), as described previously (Hozzein et al., 2004). Strain YIM $70081^{\mathrm{T}}$ was isolated from a saline soil sample from China using a modified glycerol/asparagine agar medium (ISP 5) (Shirling \& Gottlieb, 1966) supplemented with $15 \%(\mathrm{w} / \mathrm{v})$

The GenBank/EMBL/DDBJ accession numbers for the 16S rRNA gene sequences of strains YIM $70009^{\top}$ and $\mathrm{YIM} 70081^{\top}$ are AY588277 and AY588278, respectively.

Electron micrographs of strains $\mathrm{YIM} 70009^{\top}$ and $\mathrm{YIM} 70081^{\top}$ are available as supplementary material in IJSEM Online.
$\mathrm{MgCl}_{2} \cdot 6 \mathrm{H}_{2} \mathrm{O}$. Isolation plates were incubated at $28^{\circ} \mathrm{C}$ for 2 weeks. The purified strains were cultivated and maintained on modified TSA medium containing 5-10\% $\mathrm{NaCl}(\mathrm{w} / \mathrm{v}), \mathrm{pH} 8 \cdot 0-9 \cdot 0$ for strain YIM $70009^{\mathrm{T}}$ or $5-10 \%$ $\mathrm{MgCl}_{2} \cdot 6 \mathrm{H}_{2} \mathrm{O}(\mathrm{w} / \mathrm{v})$, $\mathrm{pH} 7 \cdot 0-8 \cdot 0$ for strain YIM $70081^{\mathrm{T}}$. Biomass for chemical and molecular systematic studies was grown in shaken flasks (about 150 r.p.m.) at $28^{\circ} \mathrm{C}$ for 1 week using the same media as above without agar. Morphological properties were examined by light microscopy (Olympus microscope $\mathrm{BH}-2$ ) and electron microscopy (JEOL JEM-1010).

The $\mathrm{G}+\mathrm{C}$ contents of isolates YIM $70009^{\mathrm{T}}$ and YIM $70081^{\mathrm{T}}$, determined using the thermal denaturation method of Marmur \& Doty (1962), were 64.0 and $64 \cdot 5 \mathrm{~mol} \%$, respectively. $16 \mathrm{~S}$ rRNA genes were analysed as described previously (Li et al., 2004). Phylogenetic analysis was performed using the software packages PHYLIP (Felsenstein, 1993) and MEGA (Molecular Evolutionary Genetics Analysis) version 2.1 (Kumar et al., 2001) after multiple alignment of data by CLUSTAL_X (Thompson et al., 1997). Distances were calculated using distance options according to the Kimura two-parameter model (Kimura, 1980, 1983) and clustering was performed using the neighbour-joining 


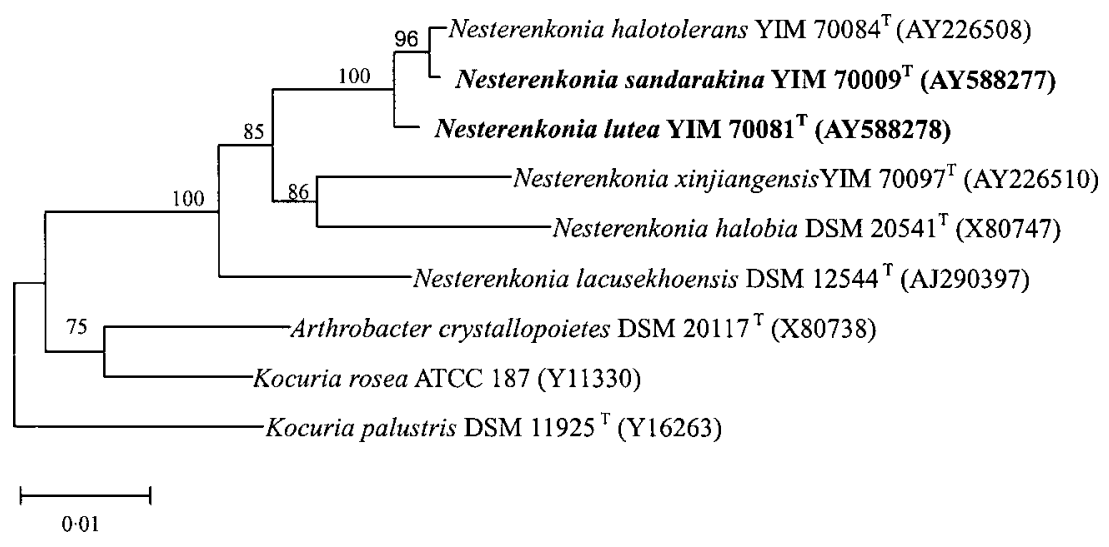

Fig. 1. Phylogenetic dendrogram, obtained by distance matrix analysis of $16 \mathrm{~S}$ rRNA gene sequences, showing the position of

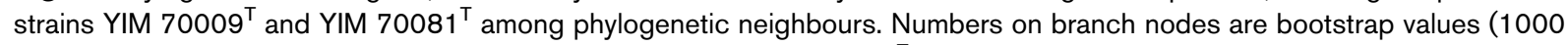
resamplings). The sequence of Streptomyces megasporus DSM $41476^{\top}$ (GenBank/EMBL/DDBJ accession no. Z68100) was used as a root. Bar, $1 \%$ sequence divergence.

method (Saitou \& Nei, 1987). Bootstrap analysis was used to evaluate tree topology of the neighbour-joining data by performing 1000 resamplings (Felsenstein, 1985). The neighbour-joining tree (Fig. 1) indicated that strains YIM $70009^{\mathrm{T}}$ and YIM $70081^{\mathrm{T}}$ were highly related to each other ( $99 \cdot 4 \%$ sequence similarity) and to $N$. halotolerans YIM $70084^{\mathrm{T}}(99 \cdot 8$ and $99 \cdot 4 \%$ sequence similarity, respectively), forming a distinct branch with this species. Sequence similarities between strains YIM $70009^{\mathrm{T}}$ and YIM $70081^{\mathrm{T}}$ and other members of the genus Nesterenkonia were no more than $97 \cdot 2 \%$.

Growth at various $\mathrm{pH}$ values and salt concentrations was tested as reported by Tang et al. (2003), except that TSA medium was used as the basic medium. Strains were grown on TSA medium containing $0,1,3,5,10,15,20,25$ or $30 \%$ $(\mathrm{w} / \mathrm{v})$ total salts $\left(\mathrm{NaCl}, \mathrm{KCl}\right.$ or $\left.\mathrm{MgSO}_{4} \cdot 6 \mathrm{H}_{2} \mathrm{O}\right)$ and at initial $\mathrm{pH}$ values of $4 \cdot 0,5 \cdot 0,6 \cdot 0,7 \cdot 0,8 \cdot 0,9 \cdot 0,10 \cdot 0,11 \cdot 0,12 \cdot 0$ and $13 \cdot 0$ for 30 days at $28^{\circ} \mathrm{C}$. Cell morphology and motility, physiological and biochemical test results, and chemotaxonomic properties, determined using previously described methods (Li et al., 2004), are given in detail in Table 1 and the species description.

DNA-DNA relatedness tests were performed between YIM $70009^{\mathrm{T}}$, YIM $70081^{\mathrm{T}}$ and N. halotolerans YIM $70084^{\mathrm{T}}$ using the optical renaturation method (De Ley et al., 1970; Huß et al., 1983; Jahnke, 1992). DNA-DNA reassociation values of $N$. halotolerans YIM $70084^{\mathrm{T}}$ with strains YIM $70009^{\mathrm{T}}$ and YIM $70081^{\mathrm{T}}$ were $43 \cdot 3$ and $39 \cdot 1 \%$, respectively, and DNA-DNA hybridization between the two isolates was $45 \cdot 2 \%$ (repeated twice). DNA-DNA relatedness data provide decisive evidence that isolates YIM $70009^{\mathrm{T}}$ and YIM $70081^{\mathrm{T}}$, and the related type strain $N$. halotolerans YIM $70084^{\mathrm{T}}$, are members of different genomic species (Wayne et al., 1987). Genomic distinctness was also revealed by differences in a number of phenotypic characteristics (Table 1). It is therefore proposed that strains YIM
$70009^{\mathrm{T}}$ and YIM $70081^{\mathrm{T}}$ should be classified as representatives of two novel Nesterenkonia species, Nesterenkonia sandarakina sp. nov. and Nesterenkonia lutea sp. nov., respectively.

\section{Emended description of the genus Nesterenkonia Stackebrandt et al. 1995 emend. Collins et al. 2002}

The description of the genus Nesterenkonia is as given previously (Stackebrandt et al., 1995; Collins et al., 2002), but with the following amendments. Moderately halophilic or halotolerant. Some species are alkaliphilic or alkalitolerant. Peptidoglycan is of the A4 $\alpha$ type, L-Lys-Gly-L-Glu, L-Lys-L-Glu or Lys-Gly-D-Asp. The $\mathrm{G}+\mathrm{C}$ content of the DNA is $64-72 \mathrm{~mol} \%$.

\section{Description of Nesterenkonia sandarakina sp. nov.}

Nesterenkonia sandarakina [san.da.ra'ki.na. N.L. fem. adj. sandarakina (from Gr. fem. adj. sandarakinê) of orange colour].

Cells are Gram-positive, non-spore-forming cocci (see electron micrograph available as supplementary material in IJSEM Online). Colony colour on most tested media is orange-yellow. Colonies are circular, opaque and approximately $0.5-1.0 \mathrm{~mm}$ in diameter after $24 \mathrm{~h}$ at $28^{\circ} \mathrm{C}$. Growth occurs at $1-15 \%(\mathrm{w} / \mathrm{v}) \mathrm{NaCl}$ (optimum at $5 \%, \mathrm{w} / \mathrm{v})$ and pH 5.0-12.0 (optimum at 8.0-9.0). Results of some physiological and biochemical characteristics, and metabolic and enzymic properties are indicated in Table 1. Peptidoglycan type is A4 $\alpha$, Lys-Gly-D-Asp. Cell wall sugars are ribose, xylose and arabinose. Main polar lipids are diphosphatidylglycerol, phosphatidylglycerol, phosphatidylinositol and an unidentified glycolipid. Predominant menaquinones are MK-7 and MK-8. Cellular fatty acids 
Table 1. Phenotypic characteristics of strains $\mathrm{YIM} 70009^{\top}, \mathrm{YIM} 70081^{\top}$ and $N$. halotolerans YIM $70084^{\top}$

Strains: 1, YIM $70009^{\mathrm{T}}$; 2, YIM $70081^{\mathrm{T}}$; 3, N. halotolerans YIM $70084^{\mathrm{T}}$. All three strains are Grampositive, non-spore-forming coccoid cells. All are positive for catalase, milk coagulation, melanin production, growth in cellulose, and lysine decarboxylase, $\beta$-glucosidase, $\beta$-galactosidase and $\alpha$-maltosidase activities. All are negative for oxidase, $\mathrm{H}_{2} \mathrm{~S}$ and indole production, decomposition of Tween 20 and Tween 80, casein and starch, and ornithine decarboxylase, arginine dihydrolase and $\mathrm{N}$-acetylglucosaminidase activities. Maltose, sucrose, mannose, mannitol, fructose, salicin and galactose are utilized by the three strains as sole carbon sources for growth; rhamnose, acetamide, inositol, adonitol and sorbitol are not utilized. +, Positive; -, negative; w, weak reaction.

\begin{tabular}{|c|c|c|c|}
\hline Characteristic & 1 & 2 & 3 \\
\hline Motility & - & + & + \\
\hline Colony pigmentation (PYGV medium) & Orange-yellow & $\begin{array}{l}\text { Light yellow to } \\
\text { primrose yellow }\end{array}$ & $\begin{array}{c}\text { Deep } \\
\text { orange-yellow }\end{array}$ \\
\hline Optimal concn of $\mathrm{NaCl}(\%, w / v)$ for growth & 5 & $5-10$ & $5-10$ \\
\hline \multicolumn{4}{|l|}{ Range of salt concn for growth $(\%, w / v)$ : } \\
\hline $\mathrm{NaCl}$ & $1-15$ & $0-20$ & $0-25$ \\
\hline $\mathrm{KCl}$ & $1-25$ & $0-20$ & $0-25$ \\
\hline $\mathrm{MgCl}_{2} \cdot 6 \mathrm{H}_{2} \mathrm{O}$ & $1-25$ & $0-20$ & $0-25$ \\
\hline \multicolumn{4}{|l|}{ Initial $\mathrm{pH}$ for growth: } \\
\hline Range & $5 \cdot 0-12 \cdot 0$ & $6 \cdot 5-10 \cdot 0$ & $6 \cdot 5-9 \cdot 0$ \\
\hline Optimum & $8 \cdot 0-9 \cdot 0$ & $7 \cdot 0-8 \cdot 0$ & $7 \cdot 2$ \\
\hline Milk peptonization & - & + & + \\
\hline Nitrate reduction & - & + & - \\
\hline Gelatin liquefaction & + & - & + \\
\hline Ammonia production & + & - & - \\
\hline Methyl red test & + & - & - \\
\hline Vogues-Proskauer & - & - & + \\
\hline \multicolumn{4}{|l|}{ Carbon source utilization: } \\
\hline Glucose & + & $\mathrm{W}$ & + \\
\hline Ribose & + & - & - \\
\hline Xylose & + & + & - \\
\hline Dextrin & $\mathrm{W}$ & + & + \\
\hline Arabinose & $\mathrm{W}$ & $\mathrm{W}$ & - \\
\hline Cellobiose & + & + & - \\
\hline Trehalose & + & - & - \\
\hline Starch & - & + & + \\
\hline Lactose & - & - & + \\
\hline \multicolumn{4}{|l|}{ Enzymic properties: } \\
\hline Urease & - & - & + \\
\hline$\alpha$-Galactosidase & + & + & - \\
\hline$\alpha$-Glucosidase & - & + & + \\
\hline$\beta$-Glucuronidase & + & - & - \\
\hline L-Aspartate arylamidase & + & - & - \\
\hline
\end{tabular}

are $\mathrm{C}_{16: 0}(33 \cdot 11 \%)$, aiC $15: 0(27 \cdot 63 \%)$, aiC $17: 0(20 \cdot 68 \%)$, $\mathrm{C}_{14: 0}(0 \cdot 81 \%), \mathrm{C}_{15: 0}(0 \cdot 81 \%), \mathrm{C}_{17: 0}(1.46 \%), \mathrm{C}_{18: 0}$ $(2 \cdot 18 \%), \quad \mathrm{iC}_{16: 0}(6 \cdot 33 \%), \mathrm{iC}_{17: 0}(0 \cdot 47 \%), \quad \mathrm{A}-\mathrm{aiC}_{15: 1}$ $(4 \cdot 81 \%), \mathrm{G}_{-1 C_{16: 1}}(0 \cdot 82 \%)$ and $\mathrm{A}-\mathrm{aiC}_{17: 1}(0 \cdot 88 \%)$.

The type strain is YIM $70009^{\mathrm{T}}\left(=\mathrm{CCTCC}\right.$ AA $203007^{\mathrm{T}}=$ DSM $15664^{\mathrm{T}}=$ KCTC $19011^{\mathrm{T}}$ ), isolated from a soil sample collected from the eastern desert of Egypt. The DNA G $+\mathrm{C}$ content of the type strain is $64 \cdot 0 \mathrm{~mol} \%$.
Description of Nesterenkonia lutea sp. nov.

Nesterenkonia lutea (lu'te.a. L. fem. adj. lutea gold-yellow).

Cells are Gram-positive, non-spore-forming, motile cocci with flagella (see electron micrograph available as supplementary material in IJSEM Online). Colony colour on most tested media is light yellow to primrose yellow. Colonies are circular, opaque, somewhat convex and approximately $0 \cdot 5-1 \cdot 0 \mathrm{~mm}$ in diameter after $24 \mathrm{~h}$ at $28^{\circ} \mathrm{C}$. Growth occurs 
at $0-20 \%(\mathrm{w} / \mathrm{v}) \mathrm{MgCl}_{2} \cdot 6 \mathrm{H}_{2} \mathrm{O}$ (optimum at $5-10 \%$, w/v) and $\mathrm{pH} 6 \cdot 5-10 \cdot 0$ (optimum at $7 \cdot 0-8 \cdot 0$ ). Results of some physiological and biochemical characteristics, and metabolic and enzymic properties are indicated in Table 1. Peptidoglycan type is A4 $\alpha$, Lys-Gly-D-Asp. Cell wall sugars are ribose, xylose, arabinose and glucose. Predominant menaquinones are MK-8 and MK-7. Main polar lipids are diphosphatidylglycerol, phosphatidylglycerol, phosphatidylinositol and an unidentified glycolipid. Cellular fatty acids are $\mathrm{aiC}_{15: 0}(10 \cdot 27 \%), \mathrm{iC}_{16: 0}(31 \cdot 40 \%)$, aiC $_{17: 0}(15 \cdot 27 \%)$, A-aiC $15: 1(15 \cdot 12 \%), \mathrm{G}^{-i C_{16: 1}}(11 \cdot 09 \%), \mathrm{G}^{-i C_{15: 1}}(0 \cdot 84 \%)$, $\mathrm{C}_{14: 0}(0 \cdot 34 \%), 2-\mathrm{OH} \mathrm{C}_{14: 0}(0 \cdot 24 \%), \mathrm{C}_{16: 0}(5 \cdot 75 \%), \mathrm{iC}_{14: 0}$ $(0.99 \%), \mathrm{iC}_{15: 0}(0.57 \%), \mathrm{iC}_{17: 0}(0.96 \%), \mathrm{C}_{17: 1} \omega 6 c$ $(0 \cdot 36 \%), \mathrm{A}_{-a i C} 17: 1(3 \cdot 21 \%), \mathrm{iC}_{18: 0}(1.55 \%), \mathrm{C}_{18: 1} \omega 7 c$ $(1.64 \%)$ and summed feature $3\left(\mathrm{C}_{16: 1} \omega 7 c\right.$ and/or $2-\mathrm{OH}$ i- $\left.\mathrm{C}_{15: 0} ; 0 \cdot 40 \%\right)$.

The type strain is YIM $70081^{\mathrm{T}}\left(=\right.$ CCTCC AA $203010^{\mathrm{T}}=$ DSM $15666^{\mathrm{T}}=$ KCTC $19013^{\mathrm{T}}$ ), isolated from a saline soil sample from the Xinjiang Province, China. The DNA G + C content of the type strain is $64 \cdot 5 \mathrm{~mol} \%$.

\section{Acknowledgements}

The authors are grateful to Dr Peter Schumann for help with peptidoglycan analysis and Dr Jean Euzéby and Professor Dr Hans G. Trüper for support with nomenclature. This research was supported by the National Basic Research Program of China (2004CB719600), the National Natural Science Foundation of China (30270004), Yunnan Provincial Natural Science Foundation (2004C0002Q), Yunnan Education Commission Foundation (02QJ077) and the 21C Frontier Microbial Genomics and Application Center Program, Ministry of Science \& Technology (MG020101-002-1-0-0) and the International Cooperation R\&D Program, Ministry of Science \& Technology (M6-0203-00-0002), Korea.

\section{References}

Collins, M. D., Lawson, P. A., Labrenz, M., Tindall, B. J., Weiss, N. \& Hirsch, P. (2002). Nesterenkonia lacusekhoensis sp. nov., isolated from hypersaline Ekho Lake, East Antarctica, and emended description of the genus Nesterenkonia. Int J Syst Evol Microbiol 52, 1145-1150.

De Ley, J., Cattoir, H. \& Reynaerts, A. (1970). The quantitative measurement of DNA hybridization from renaturation rates. Eur J Biochem 12, 133-142.

Felsenstein, J. (1985). Confidence limits on phylogenies: an approach using the bootstrap. Evolution 39, 783-791.
Felsenstein, J. (1993). PHYLIP (phylogenetic inference package), version 3.5c. Department of Genetics, University of Washington, Seattle, WA, USA.

Hozzein, W. N., Li, W.-J., Ali, M. I. A., Hammouda, O., Mousa, A. S., Xu, L.-H. \& Jiang, C.-L. (2004). Nocardiopsis alkaliphila sp. nov., a novel alkaliphilic actinomycete isolated from desert soil in Egypt. Int J Syst Evol Microbiol 54, 247-252.

Huß, V. A. R., Festl, H. \& Schleifer, K. H. (1983). Studies on the spectrophotometric determination of DNA hybridization from renaturation rates. Syst Appl Microbiol 4, 184-192.

Jahnke, K. D. (1992). Basic computer program for evaluation of spectroscopic DNA renaturation data from GILFORD System 2600 spectrometer on a PC/XT/AT type personal computer. J Microbiol Methods 15, 61-73.

Kimura, M. (1980). A simple method for estimating evolutionary rates of base substitutions through comparative studies of nucleotide sequences. J Mol Evol 16, 111-120.

Kimura, M. (1983). The Neutral Theory of Molecular Evolution. Cambridge: Cambridge University Press.

Kumar, S., Tamura, K., Jakobsen, I. B. \& Nei, M. (2001). MEGA2: molecular evolutionary genetics analysis software. Bioinformatics 17, 1244-1245.

Li, W.-J., Chen, H.-H., Zhang, Y.-Q., Schumann, P., Stackebrandt, E., Xu, L.-H. \& Jiang, C.-L. (2004). Nesterenkonia halotolerans sp. nov. and Nesterenkonia xinjiangensis sp. nov., actinobacteria from saline soils in the west of China. Int J Syst Evol Microbiol 54, 837-841.

Marmur, J. \& Doty, P. (1962). Determination of the base composition of deoxyribonucleic acid from its thermal denaturation temperature. J Mol Biol 5, 109-118.

Saitou, N. \& Nei, M. (1987). The neighbor-joining method: a new method for reconstructing phylogenetic trees. Mol Biol Evol 4, 406-425.

Shirling, E. B. \& Gottlieb, D. (1966). Methods for characterization of Streptomyces species. Int J Syst Bacteriol 16, 313-340.

Stackebrandt, E., Koch, C., Gvozdiak, O. \& Schumann, P. (1995). Taxonomic dissection of the genus Micrococcus: Kocuria gen. nov., Nesterenkonia gen. nov., Kytococcus gen. nov., Dermacoccus gen. nov., and Micrococcus Cohn 1872 gen. emend. Int J Syst Bacteriol 45, 682-692.

Tang, S. K., Li, W. J., Wang, D., Zhang, Y. G., Xu, L. H. \& Jiang, C. L. (2003). Studies of the biological characteristics of some halophilic and halotolerant actinomycetes isolated from saline and alkaline soils. Actinomycetology 17, 6-10.

Thompson, J. D., Gibson, T. J., Plewniak, F., Jeanmougin, F. \& Higgins, D. G. (1997). The CLUSTAL_X windows interface: flexible strategies for multiple sequence alignment aided by quality analysis tools. Nucleic Acids Res 25, 4876-4882.

Wayne, L. G., Brenner, D. J., Colwell, R. R. \& 9 other authors (1987). International Committee on Systematic Bacteriology. Report of the ad hoc committee on reconciliation of approaches to bacterial systematics. Int J Syst Bacteriol 37, 463-464. 